\title{
The positivity of Helicobacter pylori Stool Antigen in patients with Hyperemesis gravidarum
}

\author{
Hiperemezis gravidarumlu hastalarda gaitada Helicobacter pylori \\ antijeni saptanması
}

\author{
İncim Bezircioğlu, Hatice Barın Elveren, Ali Baloğlu, Merve Biçer \\ Department of Obstetrics and Gynecology, Izmir Atatürk Training and Research Hospital, Izmir, Turkey
}

\section{Abstract}

Objective: We aimed to investigate the possible association between Helicobacter pylori infection and Hyperemesis gravidarum.

Material and Methods: Thirty-six pregnant women with Hyperemesis gravidarum with severe vomiting (more than 4 times a day), weight loss $(\geq 3 \mathrm{~kg}$ ), ketonuria and 36 pregnant women gestational age-matched, without nausea and vomiting attending our outpatient clinic for antenatal care were enrolled the study. Demographic data of the patients were registered. Blood samples for hemogram, serum electrolytes (sodium, potassium, chloride, and calcium), alanine aminotransferase (ALT), aspartate aminotransferase (AST), blood urea nitrogen (BUN), creatine, thyroid stimulating hormone (TSH), free T3-T4, total T3-T4, and urine samples for ketonuria, stool samples for HpSA were studied. The data of both groups were compared.

Results: Eight Hyperemesis gravidarum patients (22.2\%) and 1 control patient $(2.8 \%)$ were established HpSA positive and it was statistically significant (p:0.037). There was no significant difference between Hyperemesis gravidarum and control subjects in terms of age, gestational week, parity, educational level, socioeconomic status and smoking. There was anemia in 5 Hyperemesis gravidarum patients, 4 of them were HpSA positive. HpSA positivity was more prevalent in Hyperemesis gravidarum patients with anemia $(p=0.003)$. Severe vomiting (more than 4 times a day), heartburn, epigastric pain, duration of hospitalization (more than 4 days) and weight loss $(\geq 5 \mathrm{~kg})$ were not correlated to HpSA positivity.

Conclusion: The pregnant women with Hyperemesis gravidarum have a significantly higher prevalence of Helicobacter pylori compared with control subjects.

(J Turkish-German Gynecol Assoc 2011; 12: 71-4)

Key words: Hyperemesis gravidarum, Helicobacter pylori, Helicobacter pylori stool Antigen

Received: 2 February, 2011

Accepted: 2 March, 2011
Özet

Amaç: Hiperemezis gravidarumu ile $H$. pylori enfeksiyonu arasındaki ilişkinin araştırılması amaçlandı.

Gereç ve Yöntemler: Şiddetli kusma ( $\geq 4 /$ gün), kilo kaybı ( $\geq 3 \mathrm{~kg}$ ) ve ketonürisi olan Hiperemezis gravidarum tanılı 36 gebe kadın ile bulantı ve kusması olmayan antenatal bakım için polikliniğe başvuran gebelik haftasına göre eşleştirilmiş 36 gebe kadın çalışmaya alındı. Hastaların demografik verileri kaydedildi. Hemogram, serum elektrolitleri, ALT, AST, BUN, kreatin, TSH, fT3, fT4, total T3, total T4, için kan örneği, ketonüri için idrar örneği, $H$. pylori antijeni (HPSA) için gaita örnekleri çalışıldı. Her iki grubun verileri karşılaştırıldı.

Bulgular: Hiperemezis gravidarum grubunda 8 hastada (\%22.2), kontrol grubunda 1 hastada (\%2.8) HPSA pozitif saptandı. Bu istatistiksel olarak anlamlı idi (p:0.037). Hiperemezis gravidarum ve kontrol grubu arasında yaş, gebelik haftası, parite, eğitim düzeyi ve sosyoekonomik düzey ve sigara kullanımı açısından istatistiksel olarak anlamlı bir fark bulunmadı. Çalışma grubunda anemisi olan $(\mathrm{Hg}<11 \mathrm{~g} / \mathrm{dL})$ beş hasta vardı ve bu hastaların 4'ünde (\%80) HPSA pozitif idi. Hiperemezis gravidarumda anemisi olan hastalarda daha yüksek oranda HPSA pozitifliği saptandı $(p=0.003)$. Şiddetli kusma ( $>4 /$ gün), mide yanması, epigastrik ağnı, hastanede kalma süresi ( $\geq 4$ gün), kilo kaybı ile HPSA pozitifliği arasında korelasyon saptanamadı.

Sonuç: Hiperemezis gravidarumu olan gebe kadınların önemli bir oranında Helicobacter pylori enfeksiyonunun ile birlikte olduğu görüldü.

(J Turkish-German Gynecol Assoc 2011; 12: 71-4)

Anahtar kelimeler: Hiperemezis gravidarum, Helicobacter pylori, gaitada Helicobacter pylori antijeni.

Geliş Tarihi: 02 Şubat 2011

Kabul Tarihi: 02 Mart 2011

\section{Introduction}

Nausea and vomiting are the most common gastrointestinal diseases affecting women during pregnancy. It is encountered in approximately $80 \%$ of all pregnancies. Hyperemesis gravidarum is a clinical entity including nausea, vomiting which causes loss of weight, dehydratation, ketosis, electrolyte and acid-base imbalance and occasionally renal or hepatic failure. Hyperemesis gravidarum with the incidence of $0.3-1.5 \%$ of all live births is the most common indication of hospitalization during the first trimester (1).

Little is known about the etiology of nausea and vomiting in pregnancy. Recently, several studies performed in different populations revealed a significantly high prevalence of Helicobacter pylori among pregnant women with Hyperemesis gravidarum. The purpose of the study is to investigate the possible association between Helicobacter pylori infection and Hyperemesis gravidarum. 


\section{Material and Methods}

The present study was conducted prospectively between September 2009 and February 2010. The pregnant women with Hyperemesis gravidarum between 10 and 14 weeks of pregnancy were recruited in the study group. The inclusion criteria for the study group consisted of severe vomiting (more than 4 times a day), weight loss ( $\geq 3 \mathrm{~kg}$ ) and ketonuria. Control subjects were selected randomly among the pregnant women without nausea and vomiting of similar gestational age, attending our outpatient clinic for antenatal care during the same period of time.

The study was approved by the medical ethical committee and informed consent was obtained from all cases. Demographic data of both groups were recorded. Patients who have thyroid disease, multiple pregnancy, infection, psychological and gastrointestinal disease and patients on anti-acid or antibiotic treatment were excluded. Gestational age was determined using the first date of the last menstrual period and confirmed by ultrasonography. Blood samples were obtained for hemogram, serum electrolytes (sodium, potassium, chloride, and calcium), alanine aminotransferase (ALT), aspartate aminotransferase (AST), blood urea nitrogen (BUN), creatine, thyroid stimulating hormone (TSH), free T3-T4, total T3-T4. Urine samples for ketonuria and stool samples for HpSA were collected. Stool samples were tested for Helicobacter pylori stool antigen (HpSA) using HpSA enzyme-linked immunosorbent assay (Helicobacter Antigen Quick Castte, GENERIC ASSAYS GmbH, Germany) according to the manufacturer's instructions.

Statistical analysis was carried out using SPSS 16.0 for Windows (SPSS Inc, Chicago, III, USA) statistical software. Categorical variables were compared by Chi-square and Fisher's exact test. For continuous variables, descriptive statistics were calculated and reported as mean \pm standard deviation. Categorical variables were described using frequency distribution. Student- $t$ and Mann-Whitney-U tests were used to compare mean scores of continued variables between two groups. $P$ value of less than 0.05 was considered as statistically significant.

\section{Results}

Thirty-six pregnant women with Hyperemesis gravidarum and gestational age-matched 36 control subject were enrolled the study. The demographic data of the study and control groups were summarized in Table 1 . There were no statistically significant differences between the study groups with Hyperemesis gravidarum and control groups in terms of age, gestational week, parity, body mass index, educational level and socio-economic state, and smoking. Hyperemesis gravidarum patients were found to have a significantly higher HpSA prevalence compared to control subjects $(22.2 \%$ versus $2.8 \%$; $\mathrm{p}=0.037)$. Mean duration of hospitalization in the Hyperemesis gravidarum group was $2.7 \pm 1.8$ days. Their mean weight loss was $3.5 \pm 1.7 \mathrm{~kg}$. The gastrointestinal symptoms, ketonuria, hematological, and biochemical values of 36 patients with Hyperemesis gravidarum is presented in Table 2. In Hyperemesis gravidarum patients, anemia $(\mathrm{Hgb}<1 \mathrm{~g} / \mathrm{dL})$ was encountered in 5 patients, 4 of them were HpSA positive. The Hyperemesis gravidarum patients with anemia were found to have a significantly higher HpSA positivity compared to patients without anemia $(p=0.003)$.

Heartburn, epigastric pain, duration of hospitalization (more than 4 days) and weight loss ( $\geq 5 \mathrm{~kg}$ ) were not correlated to HpSA positivity (Table 3 ). There was no statistically significant relation between HpSA positivity and hyponatremia, hypokalemia, elevated alanine/ aspartate aminotransferase.

Table 1. The comparison of demographic data and the result of HpSA test between the study group pregnancies with Hyperemesis gravidarum and the control group pregnancies

\begin{tabular}{|c|c|c|c|}
\hline \multirow[t]{2}{*}{ Characteristics } & $\begin{array}{l}\text { Study groups } \\
{\text { with } \mathrm{HG}^{\mathrm{a}}} \\
(\mathbf{n}=\mathbf{3 6})\end{array}$ & $\begin{array}{l}\text { Control } \\
\text { groups } \\
(n=36)\end{array}$ & \multirow[t]{2}{*}{$\begin{array}{c}\mathbf{p} \\
\text { value }\end{array}$} \\
\hline & $\begin{array}{c}\text { mean } \pm \\
\text { standard } \\
\text { deviation }\end{array}$ & $\begin{array}{c}\text { mean } \pm \\
\text { standard } \\
\text { deviation }\end{array}$ & \\
\hline Age (year) & $25.1 \pm 3.8$ & $26.7 \pm 5.5$ & $\mathrm{NS}^{\mathrm{b}}$ \\
\hline Gestational week & $9.3 \pm 2.9$ & $9.6 \pm 2.5$ & NS \\
\hline \multirow{2}{*}{$\begin{array}{l}\text { Body mass index } \\
\left(\mathrm{kg} / \mathrm{m}^{2}\right)\end{array}$} & $22.9 \pm 4.7$ & $24.1 \pm 3.6$ & NS \\
\hline & $\begin{array}{l}\text { Number } \\
\text { (Percent) }\end{array}$ & $\begin{array}{l}\text { Number } \\
\text { (Percent) }\end{array}$ & \\
\hline Nulliparity & $22(62.8 \%)$ & $17(47.2 \%)$ & NS \\
\hline Primiparity & $10(27.7 \%)$ & $16(44.4 \%)$ & NS \\
\hline Multiparity & $3(8.3 \%)$ & $3(8.3 \%)$ & NS \\
\hline $\begin{array}{l}\text { Education } \\
<8 \text { year }\end{array}$ & $11(30.5 \%)$ & $20(55.6 \%)$ & NS \\
\hline $\begin{array}{l}\text { Low socio- } \\
\text { economic level }\end{array}$ & $4(11.1 \%)$ & $9(25.0 \%)$ & NS \\
\hline Smoking & 0 & $4(11.1 \%)$ & NS \\
\hline $\mathrm{HpSA}^{\mathrm{c}}$ & $8(22.2 \%)$ & $1(2.8 \%)$ & 0.037 \\
\hline \multicolumn{4}{|c|}{$\begin{array}{l}\text { aHG: Hyperemesis gravidarum } \\
\text { 'NS: Non-significant, p }>0.05 \\
\text { 'HpSA: Helicobacter pylori Stool Antigen }\end{array}$} \\
\hline
\end{tabular}

Table 2. The gastrointestinal symptoms, ketonuria, hematological, and biochemical values of 36 patients with Hyperemesis gravidarum

\begin{tabular}{|l|c|c|}
\hline Clinical and laboratory characteristics & Number & Percent \\
\hline Epigastric pain & 11 & 30.5 \\
\hline Heartburn & 18 & 50 \\
\hline Serious ketonuria $(3+, 4+)$ & 10 & 27.7 \\
\hline Anemia $(\mathrm{Hg}<11 \mathrm{~g} / \mathrm{dl})$ & 5 & 13.8 \\
\hline Hyponatremia(<136 mmol/l) & 4 & 11.1 \\
\hline Hypokalemia $(<3.6 \mathrm{mmol} / \mathrm{l})$ & 2 & 5.5 \\
\hline Elevated level of AST $(>65 \mathrm{U} / \mathrm{L})$ & 3 & 8.3 \\
\hline Elevated level of AST $(>37 \mathrm{U} / \mathrm{L})$ & 3 & 8.3 \\
\hline
\end{tabular}


Table 3. The relations between $\mathrm{HpSA}$ positivity and serious vomiting, epigastric pain, heartburn, serious ketonuria anemia, hospital stay and weight loss

\begin{tabular}{|c|c|c|c|c|c|}
\hline \multirow[t]{2}{*}{ Characteristics } & \multicolumn{2}{|c|}{$\begin{array}{l}\mathrm{HpSA}^{\mathrm{a}}(+) \\
\mathrm{n}: 8\end{array}$} & \multicolumn{2}{|c|}{$\begin{array}{c}\text { HpSA(-) } \\
\text { n:28 }\end{array}$} & \multirow[t]{2}{*}{$\begin{array}{c}\mathbf{p} \\
\text { value }\end{array}$} \\
\hline & number & percent & number & percent & \\
\hline Epigastric pain & 3 & 37.5 & 9 & 32.1 & NS \\
\hline Heartburn & 4 & 50.0 & 15 & 53.6 & NS \\
\hline $\begin{array}{l}\text { Severe ketonuria } \\
(3+, 4+)\end{array}$ & 3 & 37.5 & 8 & 28.6 & NS \\
\hline $\begin{array}{l}\text { Anemia } \\
(\mathrm{Hg}<11 \mathrm{~g} / \mathrm{dl})\end{array}$ & 4 & 50.0 & 1 & 3.6 & 0.003 \\
\hline $\begin{array}{l}\geq 4 \text { days } \\
\text { hospitalization }\end{array}$ & 3 & 37.5 & 4 & 14.3 & NS \\
\hline$\geq 5 \mathrm{~kg}$ weight loss & 1 & 12.5 & 5 & 17.8 & NS \\
\hline
\end{tabular}

\section{Discussion}

This study was planned to investigate the association between Helicobacter pylori infection and Hyperemesis gravidarum in our hospital based population.

During pregnancy, the increased level of steroid hormones and human chorionic gonadotrophin change the $\mathrm{pH}$ and motility of gastrointestinal tract. These changes favor activation of Helicobacter pylori infection. In addition, the altered humoral and cell-mediated immunity also contribute to the manifestation of a latent Helicobacter pylori infection (1). Observational studies indicated the possibility of an increased susceptibility to $H$. pylori infection in pregnancy $(1,2)$.

Most of the studies were case-control designs testing the hypothesis. The majority of them used Helicobacter pylori immunoglobulin G (IgG) antibody specific serologic tests to identify exposure to Hyperemesis gravidarum. The overall prevalence of seropositivity was between $65.0-91.5 \%$ in pregnant women with Hyperemesis gravidarum (3-8). Although some studies suggested a positive association between Hyperemesis gravidarum and Helicobacter pylori seropositivity (5-8), others could not find any association $(3,4)$. Serologic tests cannot differentiate acute and chronic infections of Helicobacter pylori, because seroconversion lasts up to months or years after recovery of the disease (9).

The HpSA test, which is an enzymatic immunoassay, detects bacterial antigens of an actual ongoing infection in the stool (10). There were a few studies which used HpSA tests to identify exposure to Hyperemesis gravidarum. The overall prevalence of HpSA was between 22.6-52.53 \% in pregnant women with Hyperemesis gravidarum (11-15). The prevalence was found lower by HpSA tests than serologic tests. We determined that the pregnant women with Hyperemesis gravidarum have a significantly higher prevalence of Helicobacter pylori compared with control subjects $(22.2 \%)$. The prevalence in Karadeniz et al's. study (22.6\%) was nearest to the rate of our study (11). However, the difference in prevalence between study and control groups did not reach significant level due to the small number of subjects.

Some of the patients who had Helicobacter pylori seropositivity were asymptomatic. Asymptomatic patients were thought to have mild infection or ongoing seroconversion. The studies did not demonstrate any significant association between Helicobacter pylori seropositivity and gastrointestinal symptoms such as heartburn, epigastric pain or the duration and severity of symptoms and objective data which demonstrate severity of the disease $(14,16)$. HpSA tests are qualitative tests and show the presence of antigen. Our data also did not demonstrate any significant association between HpSA positivity and objective data which show severity of the disease such as weight loss, ketonuria and duration of hospitalization in pregnant women with Hyperemesis gravidarum. However, the study in which Helicobacter pylori infection was diagnosed by endoscopic evaluation and biopsy also revealed higher prevalence of Helicobacter pylori infection in pregnant women with severe Hyperemesis gravidarum than control subjects (17). Furthermore, the severity of Helicobacter pylori infection associated with the degree of gastric complaints and the symptoms of Hyperemesis gravidarum were suggested (17).

Various prevalence rates for Helicobacter pylori infection were reported depending on differences in the patient population studied. Although lower socio economic status was stated to be an important risk factor for Helicobacter pylori infection in pregnant women with Hyperemesis gravidarum (11), we did not find any association between low socioeconomic state and Helicobacter pylori infection. We also did not find a statistically significant relation between socio-economic status and Hyperemesis gravidarum. This may due to the low number of cases in both research and control groups. So, there is a need to carry out research with higher a number of patients.

Helicobacter pylori infection leads to iron deficiency anemia by decreasing iron absorption, bleeding of gastritis or to capture and use of iron by Helicobacter pylori (18). The positive relationship between iron deficiency anemia and Helicobacter pylori infection was also demonstrated in pregnant patients $(19,20)$. In this study, it was found that the pregnant women with Hyperemesis gravidarum and positive HpSA have higher prevalence of iron deficiency anemia.

Although the studies on this topic were considerably heterogenic, a recent review of the studies indicates that exposure to Helicobacter pylori was associated with a 3.32 times increased risk of Hyperemesis gravidarum (95\% CI:2.25-4.90) (16). Our data also demonstrated that the prevalence of Helicobacter pylori was significantly higher in pregnant women with Hyperemesis gravidarum compared with control subjects. The limitation of the study was the small number of cases. Understanding the role of Helicobacter pylori infection in the pathogenesis of Hyperemesis gravidarum and why some patients were asymptomatic need more endoscopic studies.

\section{Conflict of interest}

No conflict of interest was declared by the authors. 


\section{References}

1. Verberg MF, Gillott DJ, Al-Fardan N, Grudzinskas JG. Hyperemesis gravidarum, a literature review. Hum Reprod Update 2005; 11: 527-39.

2. Lanciers S, Despinasse B, Metha DI, Blecker U. Increased susceptibility to Helicobacter pylori infection in pregnancy. Infect Dis Obstet Gynecol 1999; 7: 195-8. [CrossRef]

3. Berker B, Soylemez F, Cengiz SD, Kose SK. Serologic assay of Helicobacter pylori infection. Is it useful in Hyperemesis gravidarum? J Reprod Med 2003; 48: 809-12.

4. Lee RH, Pan VL, Wing DA. The prevalence of Helicobacter pylori in the Hispanic population affected by Hyperemesis gravidarum. Am J Obstet Gynecol 2005; 193: 1024-7. [CrossRef]

5. Kocak I, Akcan Y, Ustun C, Demirel C, Cengiz L, Yanik FF. Helicobacter pylori seropositivity in patients with Hyperemesis gravidarum. Int J Gynaecol Obstet 1999; 66: 251-4.

6. Salimi-Khayati A, Sharami H, Mansour-Ghanaei F, Sadri S, Fallah MS. Helicobacter pylori aeropositivity and the incidence of Hyperemesis gravidarum. Med Sci Monit 2003; 9: 12-5.

7. Frigo P, Lang C, Reisenberger K, Kölbl H, Hirschl AM. Hyperemesis gravidarum associated with Helicobacter pylori seropositivity. Obstet Gynecol 1998; 91: 615-7. [CrossRef]

8. Mansour GM, Nashaat EH. Role of Helicobacter pylori in the pathogenesis of Hyperemesis gravidarum. Arch Gynecol Obstet 2010. [CrossRef]

9. Gisbert JP, Pajares JM. Stool antigen test for the diagnosis of Helicobacter pylori infection: A systematic review. Helicobacter 2004; 9: 347-68. [CrossRef]

10. Dino V, Chiara R, Carmela A, Luigi G, Sonia B, Mario M. The clinical role of stool test (HpSA) in non invasive diagnosis of Helicobacter pylori infection. Turk J Gastroenterol 2000; 11: 97-102.

11. Karadeniz RS, Ozdegirmenci O, Altay MM, Solaroglu A, Dilbaz S, Hizel N, et al. Helicobacter pylori seropositivity and stool antigen in patients with Hyperemesis gravidarum. Infect Dis Obstet Gynecol 2006; 2006: 73073. [CrossRef]

12. Aytac S, Türkay C, Kanbay M. Helicobacter pylori stool antigen assay in Hyperemesis gravidarum: a risk factor for Hyperemesis gravidarum or not? Dig Dis Sci 2007; 52: 2840-3.

13. Cevrioglu AS, Altindis M, Yilmazer M, Fenkci IV, Ellidokuz E, Kose S. Efficient and non-invasive method for investigating Helicobacter pylori in gravida with Hyperemesis gravidarum: Helicobacter pylori stool antigen test. J Obstet Gynaecol Res 2004; 30: 136-41. [CrossRef]

14. Shirin H, Sadan O, Shevah O, Bruck R, Boaz M, Moss SF, Everon S, Glezerman M, Avni Y. Positive serology for Helicobacter pylori and vomiting in the pregnancy. Arch Gynecol Obstet 2004; 270: 10-4. [CrossRef]

15. Ozdil M, Kucukkomurcu S, Ozakin C, Ozerkan K, Gencler B, Orhan O. Helicobacter pylori infection in the etiopathogenesis of Hyperemesis gravidarum. J Turkish-German Gynecol Assoc 2008; 9: 14-9.

16. Sandven I, Abdelnoor M, Nesheim Melby KK. Helicobacter pylori infection and hyperemesis gravidarum: a systematic review and meta-analysis of case-control studies. Acta Obstet Gynecol Scand 2009; 88: 1190-200. [CrossRef]

17. Bagis T, Gumurdulu Y, Kayaselcuk F, Yılmaz ES, Kıllıcadag E, Tarim E. Endoscopy in Hyperemesis gravidarum and Helicobacter pylori infection. Int J Gynaecol Obstet 2002; 79: 105-9. [CrossRef]

18. DuBois S, Kearney D. Iron-de-ciency anemia and Helicobacter pylori infection: A review of evidence. Am J Gastroenterol 2005; 100: 453-9.

19. Weyermann M, Rothenbacher D, Gayer L, Bode G, Adler G, Grab D, Flock F, Brenner H. Role of Helicobacter pylori infection in iron deficiency during pregnancy. Am J Obstet Gynecol 2005; 192: 548-53. [CrossRef]

20. Mulayim B, Celik NY, Yanik FF. Helicobacter pylori infection detected by $14 \mathrm{C}$-urea breath test is associated with iron deficiency anemia in pregnant women. J Obstet Gynaecol Res 2008; 34: 980-5. [CrossRef]

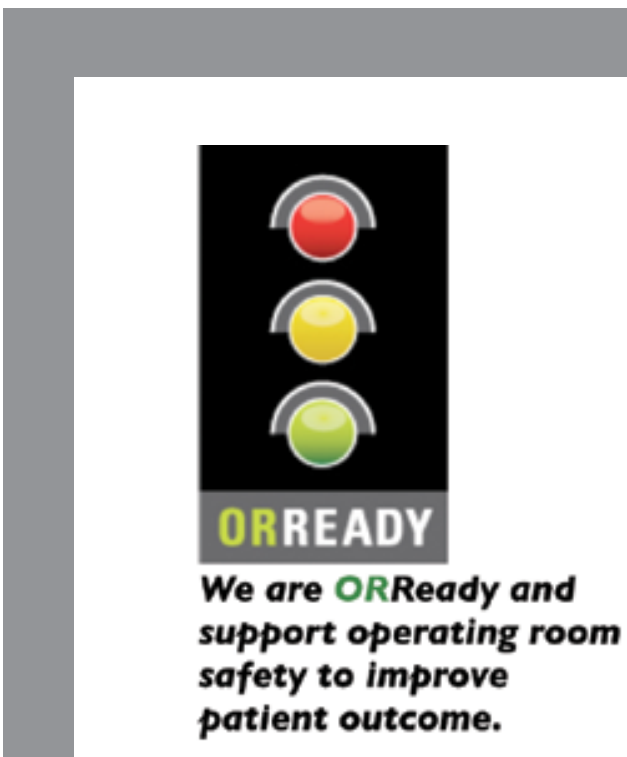

ORReady is a worldwide, multi-Specialty initiative to encourage steps that are known to improve surgical outcomes and save lives.

If the suggested guidelines, which include Check Lists, Time Outs and Warm Ups are followed routinely, we estimate that Six Million patients around the world could have better outcomes.

Find out how your department and hospital can be ORReady and improve outcomes at http://www.sls.org/outcome 